\title{
True Prevalence and Spatial Distribution of Equine Infectious Anemia Virus (EIAV) in Horses from Northeast Region of Brazil
}

\author{
Camila de Sousa Bezerra ${ }_{\odot}^{1}$, Denize Monteiro dos Anjos ${ }_{\odot}^{2}$, Brunna Muniz Rodrigues Falcão ${ }_{\odot}^{1}$, \\ Cícero Wanderlô Casimiro Bezerra ${ }^{1}$, Davidianne de Andrade Moraes ${ }_{\odot}^{1}$, Denise Batista Nogueira ${ }^{3}$, \\ Maria Luana Cristiny Rodrigues Silva ${ }^{1}$, Clebert José Alves ${ }^{1}$, \\ Carolina de Sousa Américo Batista Santos ${ }_{\odot}^{1}$ \& Sérgio Santos de Azevedo ${ }_{\odot}^{1}$
}

\begin{abstract}
Background: Equine infectious anemia (EIA) is a viral infection, caused by a lentivirus of the Retroviridae family, Orthoretrovirinael subfamily and its occurrence generates significant economic losses due to culling of positive animals as a measure of infection control. The objective of this work was to determine the prevalence of horses positive for equine infectious anemia virus (EIAV) and to identify the occurrence of areas with higher densities of cases in the states of Paraíba $(\mathrm{PB})$, Pernambuco (PE), Rio Grande do Norte (RN) and Ceará (CE), Northeast region of Brazil, during the rainy (May and June) and dry (October and November) periods of 2017 and 2018.

Materials, Methods \& Results: Serum samples from 6,566 horses from the states of PB, PE, RN and CE, Brazil, provided by the Laboratório Veterinária Diagnóstico - Ltda., were used. Serological diagnosis of EIA was performed using indirect enzyme-linked immunosorbent assay (ELISA) as a screening test and agar gel immunodiffusion test (AGID) as a confirmatory test. The apparent prevalence was obtained by dividing the number of seroreactive animals by the total number of animals, while the true prevalence was estimated by adjusting the apparent prevalence, considering the sensitivity (100\%) and specificity (98.6\%) of the diagnostic protocol used. For the construction of Kernel estimates, the Quartic function was used. In the dry season, of the 1,564 animals sampled, 28 were serologically positive, of which 19 belonged to the state of Ceará, 7 to Paraíba and 2 to Rio Grande do Norte. In 2018, it was observed that, during the rainy season, 26 of the 1,635 horses were seroreactive, with 19 cases resulting from Ceará, 4 from Paraíba and 3 from Pernambuco. In the dry season, 32 of the 1,526 animals were seroreactive to EIAV, of which 26 were from Ceará, 3 from Paraíba, 1 from Rio Grande do Norte and 2 from Pernambuco. In the dry period of 2017, the CE had a real prevalence of $1.22 \%$ (95\% CI $=0.05-2.99 \%$ ). In 2018, during the rainy season, prevalences of $0.03 \%(95 \% \mathrm{CI}=0-1.18 \%)$ were identified in $\mathrm{CE}$ and $1.69 \%(95 \% \mathrm{CI}=$ $0-8.38 \%$ ) in PE. Regarding the 2018 dry period, a prevalence of $1.32 \%$ (95\% CI $=0.26-2.84 \%$ ) was found in the state of CE. In both dry and rainy periods of 2017, the presence of spatial clusters of animals positive for EIA was observed, mainly in the border areas among the states of CE, PE, PB and RN. In 2018, there was a variation in the distribution of areas with higher densities of cases between the rainy and dry periods.

Discussion: The state of CE had the highest prevalence of positive animals and the presence of areas with higher densities of EIA cases in both climatic periods, in the years 2017 and 2018. In some municipalities of the CE, important sporting events of agglomeration of animals take place, which can favor the transmission of EIAV by facilitating the contact of infected and susceptible animals. Population density may be a factor associated with the higher prevalence observed in this region, as it has the second largest herd among the states studied. Higher densities indirectly contribute to the occurrence of infectious diseases, as they favor the contact of infected and susceptible animals. The occurrence of higher densities of cases in the border areas of the states of PE, RN, CE, and PB may be related to the greater movement of animals in these regions, favoring the indirect contact of infected horses with susceptible ones. The observed results demonstrate the circulation of the EIAV in four states in the Northeast region of Brazil.
\end{abstract}

Keywords: Equine infectious anemia virus, prevalence, spatial clusters, epidemiology.

DOI: $10.22456 / 1679-9216.116488$ 


\section{INTRODUCTION}

Equine infectious anemia (EIA) is a viral infection caused by a lentivirus of the Retroviridae family and Orthoretrovirinael subfamily [10]. Similar to other retroviruses, the EIA virus (EIAV) performs reverse transcription by the reverse transcriptase enzyme (RT), producing proviral DNA, which is integrated into the host cell DNA [7,11], allowing the occurrence of persistently infected animals.

The prevalence of EIAV has already been described in some Brazilian states through seroprevalence studies, in which variable viral circulation data were obtained, from $0.44 \%$ in Minas Gerais [1] to $17.2 \%$ in the state of Mato Grosso [2].

EIAV infection belongs to one of the eleven notifiable diseases specific to horses listed by the World Organization for Animal Health (OIE), and its occurrence generates significant economic losses, since according to Normative Instruction No. 45 of the Ministry of Agriculture, Livestock and Supplies (MAPA) in Brazil, positive animals should be culled as a measure of infection control [12].

The effective Brazilian herd has approximately 5.9 million horses, of which more than 1.3 million belong to the Northeast region [9], where the activity has economic, sporting and cultural values, however there is no comprehensive work on the circulation of the EIAV in this region. Thus, the objective of this study was to determine the prevalence of animals positive for EIAV and to identify the occurrence of areas with higher densities of cases of infection in the states of Paraíba (PB), Pernambuco (PE), Rio Grande do Norte (RN) and Ceará (CE) in Northeast region of Brazil, during the rainy (May and June) and dry (October and November) periods of 2017 and 2018.

\section{MATERIALS AND METHODS}

\section{Study area and sampling}

The samples of this study were collected in the states of Paraíba (7¹4'23.86”'S; 36 46 '55.02'W), Pernambuco (8॰48'49.39's; 36 57'14.79'”W), Rio Grande do Norte (5'24'9.29’'S; 36 57'14.79'”) and Ceará (5'29'54.06”'S; 39¹9'9.95'”), located in the Northeast region of Brazil (Figures 1 and 2), characterized by having a semiarid climate, irregular rainy season and high temperatures [16]. The effective herd of horses in each state is 62,305 in Paraíba, 125,968 in Pernambuco, 67,444 in Rio Grande do Norte and 121,110 in Ceará [9].

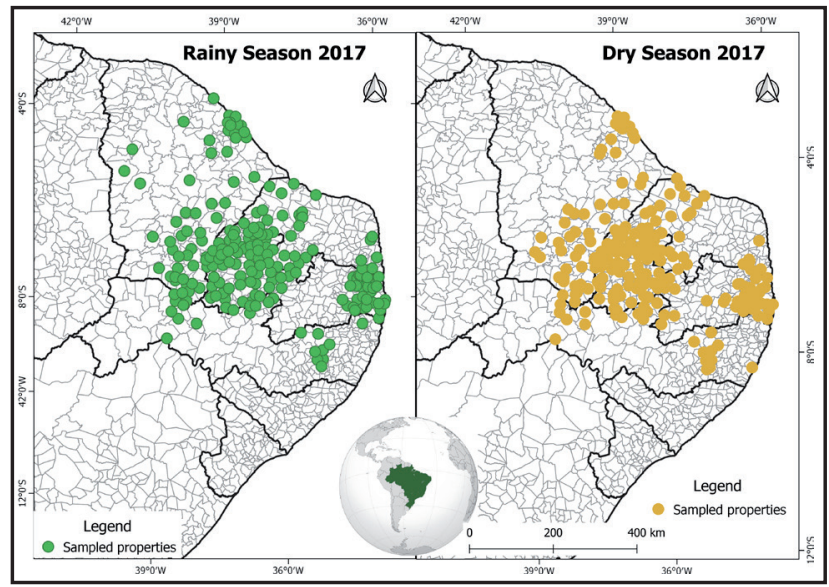

Figure 1. Distribution of properties tested for EIA, in the states of PB, PE, CE and RN, in the rainy and dry season of 2017.

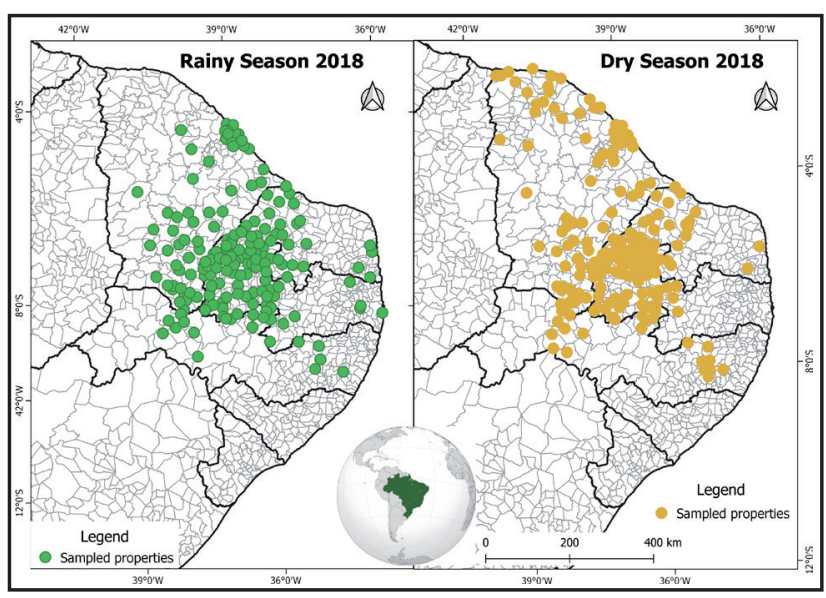

Figure 2. Distribution of properties tested for EIA, in the states of PB, PE, CE and RN, in the rainy and dry season of 2018.

All samples were provided by the Laboratório Veterinária Diagnóstico - Ltda., located in the municipality of Catolé do Rocha, PB. The laboratory is accredited by MAPA, through SDA Ordinance No. 120 , of July 9, 2014, to carry out diagnostic tests for EIA and glanders. In order to assess the prevalence of EIAV-positive animals according to the climatic season, data were collected from the rainy season (May and June) and the dry season (October and November), from the years 2017 and 2018 [8]. In total, 6,566 samples were used, with 1,841 in the rainy season of 2017 and 1,635 in the dry season of the same year; the number of samples used in the rainy and dry seasons in 2018 was 1,564 and 1,526, respectively (Table 1 ). 


\section{Serological diagnosis}

The serological diagnosis of EIA was performed at Laboratório Veterinária Diagnóstico - Ltda., using the indirect enzyme-linked immunosorbent assay (ELISA) ${ }^{1}$ as a screening test and agar gel immunodiffusion test (AGID) ${ }^{2}$ as a confirmatory test, following the recommendations of the manufacturers of commercial kits. Both tests are deemed official for the detection of EIAV antibodies, according to the National Equine Health Program (PNSE) [5].

\section{Data analysis}

Apparent and true prevalences were calculated according to Noordhuizen et al. [13]. Apparent prevalence was obtained by dividing the number of seroreactive animals by the total number of animals, while true prevalence was estimated by adjusting the apparent prevalence considering sensitivity (100\%) and specificity (98.6\%) of the diagnostic protocol used [14] according to this formula:

$$
R P=\frac{(A P+E S P-1)}{(S E N+E S P-1)}
$$

Where,

$\mathrm{TP}=$ true prevalence

$\mathrm{AP}=$ apparent prevalence

$\mathrm{ESP}=$ specificity

SEN = sensitivity

\section{Determination of case densities}

The maps were made from a database prepared in Excel spreadsheets, with subsequent spatialization in the QGIS vs 3.10 (LTR) software, forming point shapifile files for the construction of Kernel density maps for the occurrence of positive cases within the municipalities. All data were georeferenced with Universal Transverse Mercator coordinates - UTM and Datum Sirgas2000.

For the construction of Kernel estimates, the Quartic function was used, which represents events within a region of influence, estimating them by the distance of each one to a location of interest [6]. For the Kernel estimation, a radius of $50 \mathrm{~km}$ was adopted between the positive cases within each municipality.

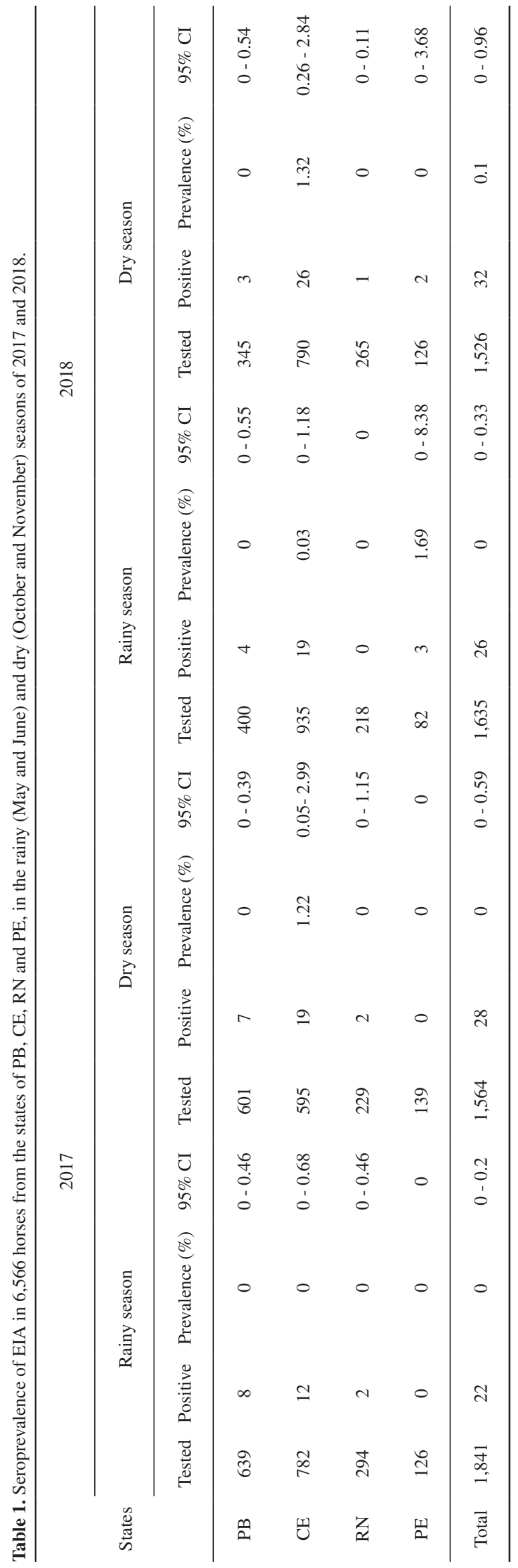




\section{RESULTS}

Figures 1 and 2 show the spatial distribution of the investigated municipalities. In 2017, 207 municipalities were evaluated in the dry season and 207 in the rainy season, and in 2018, 197 and 181 municipalities, respectively. During the 2017 rainy season, 22 of the 1,841 animals tested were positive for EIAV (12 from Ceará, 8 from Paraíba and 2 from Rio Grande do Norte). In the dry season, of the 1,564 animals sampled, 28 were positive, of which 19 belonged to the state of Ceará, 7 to Paraíba and 2 to Rio Grande do Norte. There was no positive result in the state of Pernambuco in 2017. In 2018, 26 of the 1,635 horses were seroreactive, being 19 in Ceará, 4 in Paraíba and 3 in Pernambuco, with no positive cases in the state of Rio Grande do Norte. In the dry season, 32 of the 1,526 animals were seroreactive, of which 26 were from Ceará, 3 from Paraíba, 2 from Pernambuco and 1 from Rio Grande do Norte (Table 1).

Considering the sensitivity $(100 \%)$ and specificity $(98.6 \%)$ of the diagnostic protocol used [14], true prevalences for each state were determined (Table 1). The highest prevalences were $1.22 \%$ (95\% CI $=0.05$ $-2.99 \%$ ) in the 2017 dry period, and $1.32 \%$ (95\% CI $=0.26-2.84 \%$ ) in the 2018 dry period, both for CE.

Figures 3 and 4 show the densities of EIA cases in the dry and rainy periods of 2017 and 2018, respectively, in which the lowest density of cases (1) is visualized in blue and the highest (4) in red.

In both the dry and rainy periods of 2017, the presence of clusters of animals positive for EIA was observed, mainly in the border areas among the states of CE, PE, PB and RN. The highest densities of cases were located in the intermediate regions of Quixadá (dry period), Iguatu and Juazeiro do Norte, state of CE, and in the intermediate region of Patos, state of PB. There were also clusters in the intermediate regions of João Pessoa in PB, Fortaleza in CE and Mossoró (rainy season) in $\mathrm{RN}$.

Regarding the 2018 data, there was variation in the distribution of case densities between the rainy and dry periods. In the rainy season, the EIAV cases belong to the intermediate regions of Petrolina, in the state of PE, to Sousa-Cajazeiras and Patos, in the state of $\mathrm{PB}$, and to the regions of Caicó and Mossoró, in the state of RN. The state of CE has the largest number of clusters of cases in the rainy season, distributed in the intermediate regions of Juazeiro do Norte, Iguatu,
Crateús, Fortaleza and Quixadá, the latter being the one with the highest density of cases. In the dry period, two denser areas are evidenced, one in the border areas of the states of PE, PB, RN and CE and the other in the regions of Sobral and Fortaleza in the state of $\mathrm{CE}$, in which there was a higher density of EIA cases.

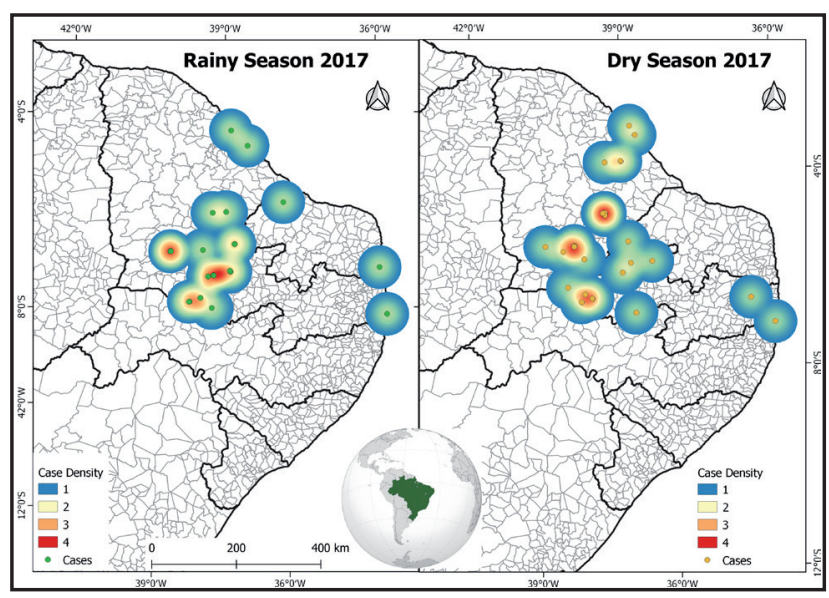

Figure 3. Distribution of densities of seroreactive animals for EIA, in the states of PB, PE, CE and RN, in the rainy and dry season of 2017.

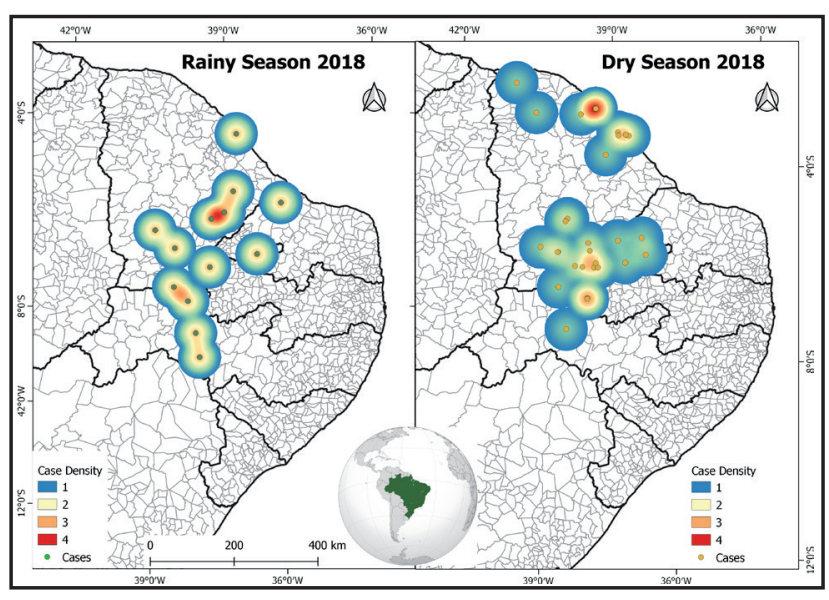

Figure 4. Distribution of densities of seroreactive animals for EIA, in the states of PB, PE, CE and RN, in the rainy and dry season of 2018.

\section{DISCUSSION}

A representative number of animals from the 4 sampled states was used, however, the absence of more than one laboratory as a data source was a limiting factor in the sampling design, with areas from which no data were obtained. However, the use of a serum bank is important in epidemiological characterization studies [15], as it allows the identification of circulating infections in the herd, as well as their periodicity, in addition to the evaluation of economic losses related to it. 
To calculate the true prevalence, the sensitivity and specificity values of the diagnostic test used are taken into account, as well as the apparent prevalence, so that the proportions of false-positive and false-negative results can be quantified. In most sample groups, the real prevalence was 0 , a reflection of possible false-positives. However, the $95 \%$ CI allows for a better assessment of the true prevalence, since it determines the variation of the value found, for example, the true prevalence of the 2017 dry period in the state of Paraíba was equal to zero, however the $95 \%$ CI was from 0 - 0.39 , indicating a possible variation in prevalence between these values.

Among the 4 states studied, the CE had the highest prevalence of positive animals (Table 1) and the highest densities of EIA cases in both climatic periods, in 2017 and 2018. In some municipalities in the state of Ceará, such as Jaguaribe, Brejo Santo, Juazeiro do Norte, Mauriti, Milagres and Aurora, there are important sporting events of agglomeration of animals coming from several regions of the state and neighboring states. Such events must respect prophylactic measures for infections [4], such as the mandatory negative test for EIA. The carrying out of clandestine agricultural activities is frequent and because there is no inspection of these events, they are carried out without respecting the established sanitary measures, thus favoring the transmission of the EIAV.

Population density may be a factor associated with the higher prevalence observed in the state of $\mathrm{CE}$, since it has the second largest herd among the states used in this study [9]. Higher densities indirectly contribute to the occurrence of infectious diseases, as they favor the contact of infected and susceptible animals, and it has been identified as a risk factor for other diseases [3]. In addition, until the end of 2019, in the state of Ceará no surveillance cares was carry out in areas of EIAV outbreaks, such as blood collection from all equines on the property, which may have contributed to the maintenance of viral circulation in this region.

The occurrence of higher densities in the border areas of the states of PE, RN, CE, and PB may be related to the greater movement of animals in these regions, favoring the indirect contact of infected horses with susceptible ones. Similar data was observed in a study on the epidemiological characterization of vesicular stomatitis in the state of $\mathrm{PB}$, in which two spatial clusters were observed, both in state boundary areas, the first between the states of $\mathrm{CE}$ and $\mathrm{PB}$, and the second between RN and PB [3].

\section{CONCLUSION}

It's concluded that EIAV is circulating in horses from four states of Northeast region of Brazil, with the state of CE being the one with the highest prevalence of positive animals, as well as areas with higher densities of positive animals. Border regions among the states were areas with the greatest clusters of positive cases, thus it is necessary to reinforce the control of the movement of animals and preventive measures against infection in these places.

\section{MANUFACTURERS \\ ${ }^{1}$ IDEXX Laboratories Inc. Westbrook, ME, USA. \\ ${ }^{2}$ Laboratórios Bruch Ltda. São Paulo, SP, Brazil.}

Declaration of interest. The authors inform that there are no conflicts of interest. Authors are solely responsible for the content of the article.

\section{REFERENCES}

1 Almeida V.M.A., Oliveira C.H.S., Fiorillo K.S., Martins M.F., Leite R.C., Reis J.K.P. \& Gonçalves V.S.P. 2017. Prevalence of equine infectious anemia in stud farms in Minas Gerais, Brazil. Semina: Ciências Agrárias. 38(3): 13351346. DOI:10.5433/1679-0359.2017v38n3p1335

2 Barros M.L., Borges A.M.C., Oliveira A.C.S., Lacerda W., Souza A.O. \& Aguiar D.M. 2018. Spatial distribution and risk factors for equine infectious anaemia in the state of Mato Grosso, Brazil. Revue Scientifique et Technique de l'OIE. 37(3): 971-983. DOI:10.20506/37.3.2900

3 Bezerra C.S., Cargnelutti J.F., Sauthier J.T., Rudi W., Flores E.F., Alves C.J., Clementino I.J., Santos C.S.A.B. \& Azevedo S.S. 2018. Epidemiological situation of vesicular stomatitis virus infection in cattle in the state of Paraíba, semiarid region of Brazil. Preventive Veterinary Medicine. 160: 68-75. DOI:10.1016/j.prevetmed.2018.09.027

4 Brasil. 2011. Diário Oficial do Estado. Série 3 Ano III Nº119 Fortaleza, 22 de junho de 2011. 
5 Brasil. 2018. Diário Oficial da União. Instrução Normativa SDA n 52, de 26/11/2018. Disponível em: <http://www. in.gov.br/materia/-/asset_publisher/Kujrw0TZC2Mb/content/id/52002092/do1-2018-11-27-instrucao-normativa-n52-de-26-de-novembr>

6 Câmara G., Monteiro A.M.V., Druck S. \& Carvalho M.S. 2002. Análise espacial e geoprocessamento. In: Druck S., Carvalho M.S., Câmara G., Monteiro A.M.V. (Eds). Análise espacial de dados geográficos. Disponível em: <http:// www.escoladesaude.pr.gov.br/arquivos/File/TEXTOS_CURSO_VIGILANCIA/capacitacao_e_atualizacao_em_geoprocessamento_em_saude_3.pdf>

7 Cook R.F., Leroux C. \& Issel C.J. 2013. Equine infectious anemia and equine infectious anemia virus in 2013: A review. Veterinary Microbiology. 167(1-2): 181-204. DOI:10.1016/j.vetmic.2013.09.031

8 Guimaraes S.O., Costa A.A., Vasconcelos Jr. F.C., Silva E.M., Sales D.C., Araújo Jr. L.M. \& Souza S.G. 2016. Climate Change Projections over the Brazilian Northeast of the CMIP5 and CORDEX Models. Revista Brasileira de Meteorologia. 31(3): 337-365. DOI:10.1590/0102-778631320150150

9 Instituto Brasileiro de Geografia e Estatística (IBGE). 2019. Sistema IBGE de Recuperação Automática (SIDRA). Pesquisa da Pecuária Municipal. Tabela 3939 - Efetivo dos rebanhos, por tipo de rebanho. Disponível em: <https:// sidra.ibge.gov.br/tabela/3939>

10 International Committee on Taxonomy of Viruses (ICTV). 2019. Taxonomy history: Equine infectious anemia virus, 2019. Disponível em: <https://talk.ictvonline.org/taxonomy/p/taxonomy-history?taxnode_id=201905028>

11 Issel C.J., Cook R.F., Mealey R.H. \& Horohov D.W. 2014. Equine infectious anemia in 2014: Live with it or eradicate it? Veterinary Clinics of North America: Equine Practice. 30(3): 561-577. DOI:10.1016/j.cveq.2014.08.002

12 Ministério da Agricultura, Pecuária e Abastecimento (MAPA). 2004. Instrução Normativa $N^{\circ} 45$, de 15 de junho de 2004. Disponível em: <http://extranet.agricultura.gov.br/sislegisconsulta/consultarLegislacao.do?operacao=visua lizar \&id=8136>

13 Noordhuizen J.P.T.M., Frankena K., Van Der Hoofd C.M. \& Graat E.A.M. 1997. Application of Quantitative Methods in Veterinary Epidemiology. Wageningen: Wageningen Press, pp.63-97.

14 Singha H., Goyal S.K., Malik P., Khurana S.K. \& Singh R.K. 2013. Development, evaluation, and laboratory validation of immunoassays for the diagnosis of equine infectious anemia (EIA) using recombinant protein produced from a synthetic p26 gene of EIA virus. Indian Journal of Virology. 24(3): 349-356. DOI:10.1007/s13337-013-0149-9

15 Thrusfield M. \& Christley R. 2018. Veterinary Epidemiology. 4th edn. Oxford: John Wiley \& Sons Ltd., pp.470-475.

16 Zanella M.E. 2014. Considerações sobre o clima e os recursos hídricos do semiárido nordestino. Caderno Prudentino de Geografia. 36: 126-142. 